Research Articles

\title{
MIDCOURSE IN THE UNITED STATES: DOES UNPAID COMMUNITY PARTICIPATION REPLACE PAID WORK?*
}

\author{
Phyllis Moen ANd Vivian FieldS
}

This study examines the links between formal community participation (defined as volunteer work for an organization) in the United States and psychological well-being, focusing on retirement as a key status transition. It draws on data from 762 American retirees and not-yet-retired older workers in the midcourse years (in their 50s, 60s, and early 70s) to examine: (1) whether unpaid community participation of retirees compensates for the loss of connectedness associated with their paid career jobs, and (2) whether community participation predicts the well-being of various subgroups of retirees. We find little difference in the community participation of midcourse Americans by their retirement status. But community participation does predict the well-being of retirees, supporting a compensatory hypothesis. Dividing the sample of retirees into those who engage in post-retirement paid work and those who do not reveals a positive association between community participation and well-being for non-workers only. Community participation appears especially salutary for the well-being of some subgroups of retirees in the United States (men more than women, those with less income, and those in poor health).

\section{Retirement as a Status Transition}

The United States is a work-oriented society. Paid work is a principal source of identity and social relations, especially for men, who historically have spent their prime years of adulthood in the labor force. Paid work has become increasingly central to American women's lives as well, as their labor force attachment comes to approach that of men's. In their classic book, The Meaning of Work and Retirement, Friedmann and Havighurst (1954) developed a five-point typology of the meanings of work as: (1) a source of income, (2) a life routine structuring the use of time, (3) a source of personal status and identity, (4) a context for social interaction, and (5) a meaningful experience that can provide a sense of accomplishment.

Ageing International, Summer 2002, Vol. 27, No. 3, p. 21-48. 
Given the centrality of jobs within the broader American culture (e.g., Terkel, 1985), individuals leaving the workforce may experience stress, social isolation, and lower levels of psychological well-being. Indeed, this has been convincingly demonstrated in the broad literature on the negative impacts of unemployment (e.g., Jahoda, 1982; Kahn, 1981; Kessler, Turner, \& House, 1989; Wilson, 1995).

Robert Weiss (1990) describes the significance of what he terms relationships of community that offer individuals a sense of place and of membership in a valued collectivity. This sense of place and belonging, in turn, gives individuals feelings of personal meaning and worth. Their career jobs are key for most contemporary adults, furnishing a community of friends and workmates, a sense of place and of social meaning. Weiss points out that links with a valued collectivity (like the world of work) provide people with events, deadlines, and schedules that structure life. This may be why unemployment is consistently negatively linked with well-being, and why paid work has been shown to be beneficial for women's as well as men's health (e.g., Jahoda, 1982; Kessler et al., 1989; Waldron \& Jacobs, 1989).

Whereas unemployment can be seen as off the beaten path, retirement is very much on the beaten path as an expected, and now almost universal, status transition. If paid work gives meaning to life in the prime adult years, what provides a sense of purpose, integration, and well-being in the years following retirement?

This article investigates retirement as a status transition, producing changes in an individual's role repertoire, and having potential implications for psychological well-being. Note that we say "change" and not "reduction" in role repertoire, for retirement itself may be considered a role, one that leaves individuals time to pursue other interests which may lead to additions to his or her role repertoire. While retirement may be defined as an exit from one's career job, today's younger retirees are often engaged in some form of post-retirement paid employment. For those not seeking employment following retirement, formal community participation as a volunteer for one or more organizations may serve many of the same integrative functions as paid work, providing role identities, routines, relationships, meaningful activity, and a sense of purpose (Moen, Fields, Quick, \& Hofmeister, 2000; Putnam, 1993; Wilson, 2000; Wilson \& Musick, 1997).

If the workplace provides a key source of personal and social realization, it follows that retirement could mean a sense of marginality for some, including the loss of role identity, routines, and relationships. But either community participation (in the form of volunteering in formal organizational settings) or taking on post-retirement employment may well offer a similar sense of place and integration. Given the increases in health and longevity along with the aging of the baby boom cohort, we hold that Americans, and indeed, those in their 50s, 60s, and early 70s in other advanced industrial countries, are witnessing the development of a new life stage, what Moen (2002) terms 
midcourse. Workers and retirees in their 50s, 60s, and 70s are, in fact, midcourse between the early career building years and the debilities traditionally associated with old age. In this study we draw on data on American workers and retirees ages 50-72 in upstate New York to assess whether community participation (volunteering in an organizational setting) is related to well-being, and whether this varies by retirement status and/or by post-retirement employment status.

\section{Retirement and Community Participation}

There are two processes by which activities following retirement might "replace" participation in one's career job. First, those moving into retirement might move into new role involvements-for instance, formally volunteering for community organizations (which is especially common in both the United States and Canada), joining special interest clubs (such as gardening or bridge groups), helping friends and neighbors, or seeking out another paid job. Second, the salience of existing activities (such as community participation) may change following retirement. In other words, the value (for one's mental health) of formal community participation may increase in the absence of paid work participation.

The evidence suggests that Americans who retire do not necessarily "replace" their career jobs with community participation (Caro \& Bass, 1997; Gilespie \& King, 1985; Herzog \& Morgan, 1993). In fact, survey data show that individuals over 60 may volunteer for organizations less frequently than individuals in the general population. Chambré $(1984,1987)$ investigated whether people tend to add activities and roles to substitute for ones that are lost or whether they tend to preserve existing relations, thereby minimizing change (see also Atchley, 1989). She found that American workers (not yet retired) volunteered at higher rates than did retirees, but those who were already volunteering typically increased their degree of involvement following retirement. However, other studies point to an increase in volunteering in tandem with retirement. A random sample of Americans 60 or older in 1982 (Marriott's Seniors Volunteerism Study, 1991) found those in their late 60s had the highest rate of volunteering $(45.7 \%)$.

\section{Participation and Well-Being}

Psychological well-being is a key component of successful aging (Baltes \& Baltes, 1990; Rowe \& Kahn, 1987), but there is little consensus as to what contributes to mental health following retirement. There is, however, evidence of a relationship between role participation (for example, in paid and unpaid work) and psychological well-being. While employment has been positively related to well-being generally, scholars typically fail to consider the role of paid work at different stages in the life course (for exceptions see Moen, 
Dempster-McClain, \& Williams, 1992; Pavalko, Elder, \& Clipp, 1993). Moreover, the evidence does not show that retirement from paid work necessarily produces any diminution in mental health (e.g., George \& Maddox, 1977).

Studies of the emotional consequences of involvement in unpaid volunteer activity (Chambré, 1984, 1987; Fischer \& Schaffer, 1993; Moen, 1997; Moen et al., 2000; Okun, Stock, Haring, \& Witter, 1984) conclude that involvement in unpaid community service is also positively related to well-being, though there are isolated studies finding a negative relationship between formal activity and life satisfaction (Longino \& Kart, 1982). And an early study by Neugarten and colleagues (1961) did find a stronger relationship between activity and well-being for those in their 70s than for those in their 50s.

These two forms of participation-in the paid workforce and in unpaid community service-may both promote well-being. Or one may compensate for the other. Or doing both may produce overload and strain, effectively canceling one another out.

\section{The Embeddedness of Participation and the Cumulation of Advantage}

We draw on both role theory and the life course, role context perspective (Moen, 2001; Moen et al., 1992; Musick, Herzog, \& House, 1999; Spitze, Logan, Joseph, \& Lee, 1994) to suggest potential moderators of the links between retirement, community participation and well-being. Retirement may underscore the potential for the Matthew effect (Merton, 1968; see also Elder, 1995; O'Rand, 1995), that is, the cumulation of advantage or disadvantage over the life course. Is there an accumulation process operating for retirees located in advantaged positions in the social structure? More privileged subgroups of Americans may both participate more in their communities and/or benefit more from such community participation. Alternatively, disadvantaged Americans may benefit most from community service (e.g., Bronfenbrenner \& Morris, 1998). We consider various social locational markers of relative advantage/disadvantage: education and income, area of residence, gender, age, and marital status, as well as three important considerations of life in the midcourse: retirement status, post-retirement employment status, and physical health status.

\section{Education and Income}

People's positions in the broad social structure affect both their opportunities for meaningful social engagement and their vulnerability to stress. Accordingly, it's reasonable that this is also the case for those in retirement. Educational attainment shapes the range of strategies and options the American life course regime affords older persons in their midcourse years (Moen, 2002). For example, older men who are well educated are the most likely to continue working for pay (Hayward, Hardy, \& Grady, 1990), and correspondingly to be better off financially (Siegel, 1993). Less educated workers frequently re- 
tire early; while those who are more educated and in higher status jobs are more likely to keep their career jobs and retire later (Barfield, 1970; Boskin, 1977; Parnes \& Nestel, 1974; Streib \& Schneider, 1971).

Research has also shown that Americans with at least some college education are more apt to participate in both formal and informal volunteering (Caro \& Bass, 1995; Chambré, 1984, 1987; Herzog \& Morgan, 1993; Marriott's Seniors Volunteerism Study, 1991; Musick et al., 1999; Wilson \& Musick, 1997). Herzog and Morgan (1993) suggest that those with the highest level skills can find the most rewarding opportunities in unpaid volunteer work (as they do in paid work). Both McPherson (1981) and Kuehne and Sears (1993) found that more highly educated volunteers tend to continue volunteering longer and are most likely to volunteer for multiple organizations. Thus, education has direct effects on community participation. But it is not clear how (or whether) education moderates the links between community participation and well-being.

\section{Residential Location}

Americans in non-metropolitan areas are more vulnerable to social isolation and, therefore, may possibly benefit the most from community participation. In a study of men and women residents (ages 65 and over) in northwestern Vermont, Fengler (1984) found that those with the greatest number of resource deficits generally benefited the most (in terms of life satisfaction) from participation in formal activity (especially volunteer work as opposed to paid work). Young and Glasgow (1998) found that non-metropolitan retirees in the U.S. who were engaged in volunteer work and other types of social participation benefited the most in terms of perceived health, compared to those not similarly engaged. By contrast, Fengler, Little, and Danigelis (1983) found that urban widows living alone benefited from community participation, while such participation among older Americans in rural communities was not related to life satisfaction.

\section{Gender}

Gender also shapes the life course of older adults (Moen, 2001). Herzog and colleagues (1989) found that older women were slightly more likely than older men in the U.S. to participate in community volunteer service. The greatest difference in their study was in the 55-64 age group, with 40.3 percent of women volunteering, compared to only 33 percent of men. About equal proportions of men and women in the 65-74 age group volunteered (39.1 to 39.8 ), with 27 percent of women over 75 volunteering, compared to 25.4 percent of men.

Moreover, given their distinctive life biographies, retirement may well be a different experience for American women than for American men. When men 
leave their jobs they are exiting from a role that has typically dominated their adult years (Weiss, 1990, 1997). Women, on the other hand, commonly experience greater discontinuity, moving in and out of the labor force, and in and out of part-time jobs in tandem with shifting family responsibilities (Clausen \& Gilens, 1990; Moen \& Han, 2001; Rosenfield, 1980; Sorenson, 1983). Consequently, they are less likely to have the same duration of employment or accumulation of work experience as men (Han \& Moen, 1999; Henretta \& O'Rand, 1980; Quick \& Moen, 1998). Given occupational segregation by gender and their less stable employment histories, American women are also less likely to be covered by private pensions than are men, and those with pensions have incomes far lower than men's.

Participation in unpaid community service may also have a different meaning to women and men given the difference in their employment histories. But it is not clear whether the most advantaged in the world of paid work prior to retirement (men) will similarly be the most advantaged in terms of benefiting psychologically from community participation following retirement.

\section{Marital Status}

Marriage itself is an integrating role, one with clear emotional benefits to health (Pienta, Hayward, \& Jenkins, 2000; Waite \& Gallagher, 2000). Married persons are, by definition, less socially isolated than are those who are widowed, divorced, or never married. Consequently, community participation may be less consequential for the well-being of married, as opposed to unmarried, retirees. On the other hand, a "cumulation of advantage" perspective would suggest that married retirees would both be more apt to participate in their communities and to benefit from that participation (see also Musick et al., 1999).

\section{Retirement, Employment and Health}

Retirement itself, along with employment following retirement, may also moderate the impacts of unpaid community participation on well-being. American men and women who have made the transition to retirement (receiving a private pension, Social Security payments, or being on employers' lists of retirees) are expected to benefit the most from volunteer community service, given the absence of paid work as a source of identity, routine, and purpose. But Americans working for pay following retirement may derive the most psychological benefits from their jobs, rather than from any unpaid community participation.

We expect health to be positively related to both volunteer community participation and employment, consistent with other research evidence (e.g., Chirikos \& Nestel, 1989; Kim \& Moen, 2002; Moen, Kim, \& Hofmeister, 2001; Musick et al., 1999). But it may be that those who are the least healthy benefit less psychologically from unpaid community volunteer work. 


\section{Research Questions}

The literature on the importance of social roles (or integration) for wellbeing has not considered the potential distinctiveness of various roles or how their patterning shifts over the life course. Role theory in conjunction with a life course, role context approach suggests the following research questions:

- Does Americans' formal community participation (volunteering for a community organization) increase following retirement from their career jobs? Are changes in formal volunteer participation distinct from changes in other unpaid role involvements (informal "helping out" or engagement in purely social clubs)?

- Are volunteer community participation and post-retirement employment in the U.S. alternative, complementary, or independent roles following retirement?

- Do both paid work and unpaid community participation predict psychological well-being, or are the effects of one dependent on the other? In other words, does community participation substitute for paid work in promoting the psychological well-being of midcourse Americans, or is it merely an additional source of well-being?

- Does formal community participation (volunteering for an organization) predict well-being better than either informal "helping out" or belonging to social clubs?

- Does location in the social structure (e.g., in terms of education, area of residence, gender, health) serve to moderate the links between community participation and the well-being of American retirees?

We anticipate something of a cumulation of advantage, with those American retirees who are educated, healthy, married and male the most likely both to participate in their communities and to benefit psychologically from that participation. But it could also be the case that community participation is especially valuable for the least advantaged (Bronfenbrenner \& Morris, 1998). An alternative to the cumulation of advantage hypothesis is, therefore, that Americans who are disadvantaged are less apt to be engaged in either volunteer community participation or in paid work following retirement, but those who do participate benefit more psychologically than those who are already advantaged.

\section{Design}

\section{Sample}

This study analyzes data collected in the United States in both the first (1994/95) and the second (1996/97) waves of the Cornell Retirement and Well-Being Study (Moen, 1996; Pillemer, Moen, Wethington, \& Glasgow, 
2001). The respondents in Wave 1 were 304 older workers and 458 retirees from six large manufacturing and service organizations in four cities of upstate New York who were aged 50 to 72 at the time they were first interviewed in 1994/95. They were randomly selected from lists provided by their employers and initially contacted by letter and telephone to request their participation and arrange for an interview time and place. The interviews, ranging from one to two and one half hours, were conducted face to face (save for those who had relocated to new communities, which were conducted by telephone).

At the time of the first wave of the survey 214 (56.3\%) of the women and $244(53.3 \%)$ of the men were retired from their career jobs. These retirees were on average 63.5 years old, compared to 55.8 for those workers who were not yet retired at Wave 1 .

Wave 2 interviews were conducted in 1996/97. Over 94 percent (712) of surviving respondents from Wave 1 participated in the second wave interviews. The Wave 2 sample included 228 respondents who were not yet retired as well as 484 retired respondents. Of those who participated in both waves of the survey, 20.5 percent (59) of the respondents who were not retired at Wave 1 had retired by the time they were reinterviewed. These "newly retired" respondents were on average 3.5 years older than those who had not yet retired and 4.9 years younger than those who were already retired at Wave 1. By design, the sample was evenly divided between men and women $(50.7 \%$ to $49.3 \%)$.

\section{Variables}

The Wave 1 survey research instruments included a structured interview schedule and a booklet of self-administered questions drawn from a number of sources, including the Health and Retirement Survey (Juster, 1992) and the Quality of Employment Survey (Quinn \& Staines, 1979). In addition, we drew on data from a life history calendar based on a life history interview in Wave 1 (Han \& Moen, 1999). The Wave 2 survey consisted of a 45-minute telephone survey. These instruments were extensively pretested prior to administration.

Dependent Variables. We focus on three positive measures of well-being: general life satisfaction, self-esteem, and a sense of mastery or self-efficacy, as well as a fourth measure of depressive symptoms, the Center for Epidemiologic Studies Depression Scale (CES-D). We also include a subjective assessment of energy level as another index of general life quality. (We chose not to develop a single index of well-being since these measures capture different dimensions of psychological health-see also Ryff and Keys 1995.)

Life satisfaction is measured by a single item: "In general, how satisfying do you find the ways you're spending your life these days?" Answers are coded on a 4-point scale.

Self-esteem is captured using a scale developed by Rosenberg (1965). Respondents were asked to rate their reactions to statements such as: I feel 
that I'm a person of worth, at least on an equal plane with others; I feel I do not have much to be proud of; On the whole, I am satisfied with myself. We calculate the alpha reliability score of this measure at .87 for this sample.

Pearlin defines mastery as "the extent to which people see themselves as being in control of the forces that importantly affect their lives" (Pearlin, Menaghan, Lieberman, \& Mullan, 1981; Pearlin \& Schooler, 1978). Respondents were asked to respond to statements such as: What happens to me in the future mostly depends on me; There is little I can do to change many of the important things in my life; I often feel helpless in dealing with the problems of life. The reliability level for this measure is .82 .

The Center for Epidemiologic Studies Depression Scale (CES-D) is a selfreport measure of depression, with scores ranging from zero to thirty-six, (Radloff, 1977). As gauged by the CES-D, the prevalence of serious depression drops progressively with aging until about the age of 55, after which it rises into old age, when it peaks in the oldest age category (Newmann, 1989). In our sample, the alpha reliability score for this measure is .87 .

Energy level was self-reported on a scale of zero to ten, where 0 indicates "never have any pep or energy" and 10 indicates, "always full of pep and energy."

Independent Variables. We focus on paid work (both full and part time) following retirement and formal community participation, measured as volunteering for an organization. We also look at two other activities: informal "helping out" (for friends or neighbors) and membership in social clubs (such as bridge or garden clubs).

There is a great deal of variation in how volunteer work is defined. Some studies exclude unpaid work for one or another type of organization; others include only unpaid work for formal organizations (Tomeh, 1973). In this study we define volunteer work as any unpaid work the individual respondent defines as volunteering. Respondents were prompted to give information about their volunteering by the statement, "I'd like to ask you about any possible volunteer activities." Information about both formal (organizational) and informal volunteering was recorded. We categorize formal volunteering for an organization as community participation. It is most analogous to employment, in terms of providing routine, relationships, and purposive activity (but without income). Over half the volunteers in this study participated in their communities as members of some sort of faith-based agency. This finding is consistent with previous research (e.g., Caro \& Bass, 1995; Musick et al., 1999). There was no significant gender difference in type of community agency served. About a third of the volunteers functioned as administrative or board members for non-profit organizations, though men were more likely than women to serve in these capacities, while women were more likely to be involved with clerical tasks.

In order to obtain information about organizational membership, respondents were asked, "Are you a member of any clubs or organizations? If they 
asked for clarification, they were prompted with the suggestion, "like church groups, service groups like Rotary or Elks, work-related clubs, hobby clubs, etc." We created a four-level measure of unpaid involvement: respondent neither volunteers nor is a member of a social club; the individual volunteers but on an informal basis ("helping out" neighbors or others in need on occasion, but not doing so formally as part of an organization); the respondent is a member of a social club (such as a bridge club) but does not volunteer; the respondent formally volunteers for an agency or organization (such as participating in Boy Scouts, a church-led program to provide meals). We operationalize "formal" community participation as the latter category. This is similar to the distinction made by Wilson and Musick (1997) between formal volunteer work in an organizational context and more informal "helping out," and conforms to Musick and colleagues' (1999) definition of volunteering as in the context of an organization. An assessment of the life history data we collected in our study reinforced the construct validity of this measure, with respondents categorized as engaged in community participation doing regular activities associated with community service organizations (such as "Friends of the Library," League of Women Voters, Volunteer Fire Department).

Moderating Variables. In addition to retirement status (operationalized in this study as receiving a private pension, Social Security, or being on employers' lists of retirees), we also considered location in the social structure more generally in terms of marital status, health, education, income, and place of residence.

Marital Status: We coded respondents as married versus not currently married. Respondents who were currently separated from their spouse were considered as "not currently married" for the purpose of this study.

Health: Respondents rated their health on a scale of 0 to 10 , where 0 indicates having "very serious health problems" and 10 indicates being in the "very best of health." Respondents ratings were clustered such that over 70 percent rated themselves 8 or above. We considered those in this cluster to be in good health and everyone who rated themselves below this level to be in relatively less good health.

Education: Educational attainment was coded into three categories using information provided in the education event section of the life history calendar: high school diploma or less, some college, and college graduate or higher.

Income: Respondents were asked to report "total household income." They were instructed to include: "your (and your spouse's or partner's) wages, overtime pay, bonuses, commissions, pensions, and Social Security income. Please also include any income you receive from investments, savings, rent, alimony, etc." They then selected one of 11 categories that best described their income level. We used the mid-point of each category to assign incomes to individuals.

Place of Residence: Respondents whose addresses do not fall into Standard Metropolitan Statistical Areas were considered to be residents of non- 
metropolitan areas. All respondents were asked whether they owned their own home or rented and how long they had lived there.

\section{Methods}

We calculated means using analysis of variance to describe both characteristics of this sample of midcourse Americans and their rates of participation. We then estimate models to analyze the relationship between volunteer community participation, paid work, and well-being. For each regression, the dependent variable is a measure of well-being (mastery, self-esteem, satisfaction, energy level, or number of depressive symptoms). All of the regressions include two sets of explanatory variables. The first is the four-level (unpaid) participation variable described above (formal community participation, informal "helping out," social club member, and no participation [the omitted category in each regression]). The second set of independent variables used in all the regressions captures workforce participation. We estimate four sets of regressions. First, measures of well-being are regressed on measures of unpaid and workforce participation separately for midcourse retirees and those in the midcourse years who have not yet retired. The remaining sets of regressions are estimated for subgroups of retirees only. Note that our goal is not to "explain" well-being, but only to ascertain whether either paid work or unpaid formal community participation (or both) predicts various measures of well-being for midcourse Americans either anticipating or experiencing the retirement transition.

\section{Findings}

Table 1 describes the general characteristics of these midcourse Americans at the time of the Wave 1 interview (1994/95), showing little difference by retirement status in various forms of participation. Note that over three in ten respondents are involved in neither volunteering (formal community participation or informal "helping out") nor in clubs or organizations in their communities. But almost three in ten of the "retired" are engaged in paid work. Those in this midcourse age group who have already retired tend to have less education and less income, consistent with research showing that the more educated retire later and that Americans tend to have reduced income following retirement.

Midcourse retirees differ little in their unpaid participation from those who have not yet retired. Note (on Table 1) that about three in ten Americans in this midcourse sample engage in community volunteer activities. There are gender differences in the retirement experiences (data not shown). Retired women, tend to devote more time to volunteering than do retired men (data not shown). Fewer than half of the retired men $(45.3 \%)$ volunteer for more than 10 hours a month, while well over half $(62.2 \%)$ of the retired women put in more than 10 
Table 1

Descriptive Profiles of Paid Work and Unpaid Participation (and Other Characteristics) of Not-Yet-Retired Midcourse American Workers and Retirees (Ages 50-72) by Percent in Category

\begin{tabular}{|c|c|c|}
\hline & \multirow{3}{*}{ Not Yet Retired } & \multirow{3}{*}{ Retired } \\
\hline & & \\
\hline Unpaid Participation & & \\
\hline Informal volunteering only & $9.6 \%$ & $12.0 \%$ \\
\hline Social club member & $27.0 \%$ & $26.0 \%$ \\
\hline $\begin{array}{l}\text { Formal community participation } \\
\qquad \text { (volunteer work for organization) }\end{array}$ & $26.7 \%$ & $30.9 \%$ \\
\hline No community involvements & $36.7 \%$ & $31.1 \%$ \\
\hline \multicolumn{3}{|l|}{ Paid Participation } \\
\hline Employed & $100.0 \%$ & $28.2 \% * * *$ \\
\hline Part time & $8.6 \%$ & $17.2 \% * * *$ \\
\hline Full time & $90.8 \%$ & $10.9 \% * * *$ \\
\hline \multicolumn{3}{|l|}{ Gender } \\
\hline Male & $46.1 \%$ & $53.5 \% *$ \\
\hline Female & $53.9 \%$ & $46.7 \%$ \\
\hline \multicolumn{3}{|l|}{ Marital Status } \\
\hline Not currently married & $24.3 \%$ & $25.8 \%$ \\
\hline Currently married & $75.7 \%$ & $74.2 \%$ \\
\hline \multicolumn{3}{|l|}{ Health Status } \\
\hline Poor health & $25.3 \%$ & $30.0 \%$ \\
\hline Good health & $74.7 \%$ & $70.0 \%$ \\
\hline \multicolumn{3}{|l|}{ Educational Status } \\
\hline High school or less & $35.3 \%$ & $48.0 \% * * *$ \\
\hline Some college & $25.4 \%$ & $17.5 \%$ \\
\hline College graduate & $39.3 \%$ & $34.5 \%$ \\
\hline \multicolumn{3}{|l|}{ Income Status } \\
\hline$\leq \$ 35,000$ & $28.6 \%$ & $61.2 \% * * *$ \\
\hline$>\$ 35,000$ & $71.4 \%$ & $38.8 \%$ \\
\hline \multicolumn{3}{|l|}{ Place of Residence } \\
\hline Non-metro area & $35.1 \%$ & $31.3 \%$ \\
\hline Metropolitan area & $64.9 \%$ & $68.7 \%$ \\
\hline \multicolumn{3}{|l|}{ Age Variables } \\
\hline Ages 50-59 & $84.2 \%$ & $22.5 \% * * *$ \\
\hline Ages $60-72$ & $15.8 \%$ & $77.5 \%$ \\
\hline Mean age at interview & 55.7 & $63.5 * * *$ \\
\hline Mean age at retirement & - & 59.0 \\
\hline $\mathrm{N}$ & $\sim 304$ & $\sim 458$ \\
\hline
\end{tabular}

Significance levels: $* \mathrm{p} \leq .05 \quad * * * \mathrm{p} \leq .001 \quad$ (two-tailed tests)

Significance levels represent differences between retirees and those not yet retired. Source: Cornell Retirement and Well-Being Study, Wave 1 (1994-95) 
hours each month in volunteer activities $(\mathrm{p}=.02)$. By contrast, the men in this midcourse American sample are more likely than women to work for pay after retirement. About one third of retired men are currently employed, compared to only about one in five retired women $(\mathrm{p}=.01)$. Of those retirees who work for pay, men are twice as likely as women to work full time (14.3\% of all retired men, $7 \%$ of all retired women). Participation rates in social clubs and service organizations are also higher for men than for women $(61.5 \%$ of the men, $51.6 \%$ of the women; $\mathrm{p}=.03$ ).

Fewer of the retired women than men in this midcourse sample are married (58\% to $88 \%, \mathrm{p}=.00)$. Over a third $(37 \%)$ of the retired women live in nonmetropolitan areas, compared to only about a fourth $(26 \%)$ of the men $(\mathrm{p}=.01)$. In terms of financial resources, gender differences are even more striking. Fewer than half as many retired women as retired men live in households with incomes over $\$ 35,000$ ( $23 \%$ to $53 \%, \mathrm{p}=.00$ ). The retired men in our sample are also more advantaged in terms of education than are the women, with twice as many having a college degree ( $45 \%$ to $22.5 \%, \mathrm{p}=.000)$.

\section{Who Participates?}

In terms of paid work and unpaid community participation "substituting" for each other, we find little difference in unpaid involvements by employment or retirement status. Further analysis (Table 2) shows neither gender, marital status, place of residence, nor age group predict patterns of participation. But note that our sample includes only those in the midcourse years (in their 50s, 60s, and early 70s), groups which according to the Marriott Study (1991) tend to be high in participation.

What does matter is education. Our results are consistent with earlier research showing educational status to be positively correlated with formal volunteer participation in community organizations. Education suggests a cumulation of advantage in terms of social connectedness: those midcourse Americans with only a high school diploma (or less) are less apt to be involved in their communities, regardless of their retirement status, while college graduates (both retirees and those not yet retired) are the most likely to be participating in their communities. Participation rates among retirees by income level are also consistent with previous studies (Chambré, 1987; Herzog \& Morgan, 1993), with high income respondents more involved than those with lower incomes.

Examining similarities and differences in community participation across waves (from Wave 1 [1994/95] to Wave 2 [1996/97]) suggests little change. We find little difference in rates of community participation by retirement status or among the newly retired (those who retired between waves of the survey, see Table 3, Panel A). What distinguishes the newly retired (within the last two years) from the retired is their paid participation. The newly retired are more apt to hold jobs than are those who have been retired longer. But 
Table 2

\begin{tabular}{|c|c|c|c|c|c|c|c|c|}
\hline \multicolumn{9}{|c|}{$\begin{array}{l}\text { Who Participates? Analysis of Unpaid Participation of Subgroups of American } \\
\text { Retirees and Not-Yet-Retired Workers in the Midcourse Years (Ages 50-72) }\end{array}$} \\
\hline & Not Yet & $\begin{array}{l}\text { Retired } \\
\text { In- } \\
\text { formal } \\
\text { Volun- } \\
\text { teering } \\
\text { Only }\end{array}$ & $\begin{array}{l}\text { Social } \\
\text { Club } \\
\text { Only }\end{array}$ & $\begin{array}{l}\text { Formal } \\
\text { Com- } \\
\text { munity } \\
\text { Parti- } \\
\text { cipation }^{1}\end{array}$ & Retirees & $\begin{array}{l}(\mathrm{N} \sim 458) \\
\text { In- } \\
\text { formal } \\
\text { Volun- } \\
\text { teering } \\
\text { Only }\end{array}$ & $\begin{array}{l}\text { Social } \\
\text { Club } \\
\text { Only }\end{array}$ & $\begin{array}{l}\text { Formal } \\
\text { Com- } \\
\text { munity } \\
\text { Parti- } \\
\text { cipation }\end{array}$ \\
\hline $\begin{array}{l}\text { Work Participation } \\
\text { Not employed }\end{array}$ & & & & & $31.2 \%$ & $10.4 \%$ & $26.9 \%$ & $31.5 \%$ \\
\hline Employed & $36.7 \%$ & $9.6 \%$ & $27.0 \%$ & $26.7 \%^{2}$ & $30.2 \%$ & $16.3 \%$ & $24.0 \%$ & $29.5 \%$ \\
\hline Full time & $38.1 \%$ & $8.9 \%$ & $26.5 \%$ & $26.5 \%$ & $34.0 \%$ & $18.0 \%$ & $24.0 \%$ & $24.0 \%$ \\
\hline Part time & $20.8 \%$ & $16.7 \%$ & $33.3 \%$ & $29.2 \%$ & $15.5 \%$ & $21.8 \%$ & $16.0 \%$ & $18.4 \%$ \\
\hline \multicolumn{9}{|l|}{ Gender } \\
\hline Male & $32.3 \%$ & $10.2 \%$ & $28.3 \%$ & $29.1 \%$ & $26.6 \%$ & $11.9 \%$ & $28.7 \%$ & $32.8 \%$ \\
\hline Female & $40.3 \%$ & $9.1 \%$ & $26.0 \%$ & $24.7 \%$ & $36.2 \%$ & $12.2 \%$ & $23.0 \%$ & $28.6 \%$ \\
\hline \multicolumn{9}{|l|}{ Marital Status } \\
\hline $\begin{array}{l}\text { Not currently } \\
\text { married }\end{array}$ & $33.3 \%$ & $4.3 \%$ & $31.9 \%$ & $30.4 \%$ & $33.9 \%$ & $14.4 \%$ & $25.4 \%$ & $26.3 \%$ \\
\hline Currently married & $37.7 \%$ & $11.3 \%$ & $25.5 \%$ & $25.5 \%$ & $30.1 \%$ & $11.2 \%$ & $26.3 \%$ & $32.4 \%$ \\
\hline \multicolumn{9}{|l|}{ Health Status } \\
\hline Good health & $35.6 \%$ & $10.6 \%$ & $26.9 \%$ & $26.9 \%$ & $28.1 \%$ & $11.0 \%$ & $26.8 \%$ & $34.2 \%$ \\
\hline Poor health & $38.2 \%$ & $5.9 \%$ & $27.9 \%$ & $27.9 \%$ & $35.3 \%$ & $14.3 \%$ & $27.1 \%$ & $23.3 \%$ \\
\hline Educational Status & $* *$ & & & & $* * *$ & & & \\
\hline High school or less & $50.5 \%$ & $6.2 \%$ & $23.7 \%$ & $19.6 \%$ & $38.9 \%$ & $10.1 \%$ & $26.0 \%$ & $25.0 \%$ \\
\hline Some college & $36.6 \%$ & $12.7 \%$ & $31.0 \%$ & $19.7 \%$ & $31.6 \%$ & $9.2 \%$ & $28.9 \%$ & $30.3 \%$ \\
\hline College graduate & $25.0 \%$ & $10.7 \%$ & $26.8 \%$ & $37.5 \%$ & $18.0 \%$ & $17.3 \%$ & $20.7 \%$ & $44.0 \%$ \\
\hline Income Status & & & & & + & & & \\
\hline$£ \$ 35,000$ & $40.8 \%$ & $5.6 \%$ & $30.3 \%$ & $23.7 \%$ & $34.8 \%$ & $11.7 \%$ & $26.6 \%$ & $27.0 \%$ \\
\hline$>\$ 35,000$ & $33.9 \%$ & $11.5 \%$ & $26.0 \%$ & $28.6 \%$ & $22.8 \%$ & $13.6 \%$ & $27.2 \%$ & $36.4 \%$ \\
\hline Place of Residence & + & & & & & & & \\
\hline $\begin{array}{l}\text { Non-metropolitan } \\
\text { area }\end{array}$ & $29.3 \%$ & $9.1 \%$ & $26.3 \%$ & $35.4 \%$ & $34.0 \%$ & $12.8 \%$ & $22.0 \%$ & $31.2 \%$ \\
\hline Metropolitan area & $40.7 \%$ & $9.9 \%$ & $27.5 \%$ & $22.0 \%$ & $29.9 \%$ & $11.7 \%$ & $27.3 \%$ & $31.2 \%$ \\
\hline Age-Cohort & + & & & & & & & \\
\hline Ages 50-59 & $39.5 \%$ & $9.7 \%$ & $24.8 \%$ & $26.1 \%$ & $34.3 \%$ & $11.8 \%$ & $27.5 \%$ & $26.5 \%$ \\
\hline Ages $60-72$ & $20.9 \%$ & $9.3 \%$ & $39.5 \%$ & $30.2 \%$ & $29.9 \%$ & $12.1 \%$ & $25.7 \%$ & $32.2 \%$ \\
\hline Total & $36.7 \%$ & $9.6 \%$ & $27.0 \%$ & $26.7 \%$ & $31.1 \%$ & $12.0 \%$ & $26.0 \%$ & $30.9 \%$ \\
\hline
\end{tabular}

Significance levels: $+\mathrm{p} \leq .1 * * * \mathrm{p} \leq .01 \quad * * * \mathrm{p} \leq .001$ (two-tailed tests)

Source: Cornell Retirement and Well-Being Study, Wave 1 (1994-95)

${ }^{1}$ formal volunteer work in an organizational setting

${ }^{2}$ rows sum to $100 \%$ 
these panel data provide some additional evidence about the ebb and flow of participation across the life course (Table 3, Panel B). It is instructive that about a fourth of those in this midcourse American sample change their involvement in club membership and/or in volunteer work over a year's timeregardless of their retirement status.

Though the numbers are small, it appears that, regardless of their prior occupational status, marital status, educational level or age, about a fourth $(25 \%)$ of the newly retired are likely to begin formal volunteer participation in their communities in tandem with retirement. Newly retired women are more

Table 3

Participation Rates and Changes in Participation by Continuity and Change in Midcourse Americans' Retirement Status, Wave $1(1994 / 95)$ to Wave $2(1996 / 97)$

\begin{tabular}{|c|c|c|c|}
\hline & $\begin{array}{l}\text { Not Yet Retired } \\
(\mathrm{W} 1, \mathrm{~W} 2)\end{array}$ & $\begin{array}{l}\text { Newly Retired } \\
\text { (between W1 } \\
\text { \& W2) }\end{array}$ & $\begin{array}{l}\text { Retired } \\
(\mathrm{W} 1, \mathrm{~W} 2)\end{array}$ \\
\hline \multicolumn{4}{|l|}{ A. Participation } \\
\hline Paid work $\quad * * *$ & $100 \%$ & $41.4 \%$ & $27.3 \%$ \\
\hline Informal "helping out" only & $8.8 \%$ & $8.5 \%$ & $9.9 \%$ \\
\hline Social club member only & $24.3 \%$ & $22.0 \%$ & $26.2 \%$ \\
\hline Formal community participation & $32.3 \%$ & $39.0 \%$ & $35.9 \%$ \\
\hline No community involvements & $34.5 \%$ & $30.5 \%$ & $27.9 \%$ \\
\hline \multirow{2}{*}{\multicolumn{4}{|c|}{$\begin{array}{l}\text { B. Changes in Social Participation } \\
\text { Informal Volunteering }\end{array}$}} \\
\hline & & & \\
\hline Began informal volunteering & $15.0 \%$ & $18.6 \%$ & $12.3 \%$ \\
\hline Stopped informal volunteering & $10.6 \%$ & $6.8 \%$ & $10.7 \%$ \\
\hline No change & $74.4 \%$ & $75.6 \%$ & $77.0 \%$ \\
\hline \multicolumn{4}{|l|}{ Social Club Membership } \\
\hline Joined social club & $15.5 \%$ & $13.5 \%$ & $14.5 \%$ \\
\hline Left social club & $9.4 \%$ & $7.7 \%$ & $10.0 \%$ \\
\hline No change & $75.1 \%$ & $78.8 \%$ & $75.5 \%$ \\
\hline \multicolumn{4}{|l|}{ Community Participation } \\
\hline Began formal volunteering & $14.1 \%$ & $25.0 \%$ & $13.8 \%$ \\
\hline Left formal volunteering & $7.5 \%$ & $5.8 \%$ & $9.3 \%$ \\
\hline No change & $78.4 \%$ & $69.2 \%$ & $77.0 \%$ \\
\hline Approximate $\mathrm{N}$ & 228 & 59 & 425 \\
\hline
\end{tabular}

Signifance level:*** $\mathrm{p} \leq .001$ (two-tailed tests)

1 "Helping out"

Sample Size: N 708

Source: Cornell Retirement and Well-Being Study, Waves 1 (1994/95) and 2 (1996/97) 
Table 4

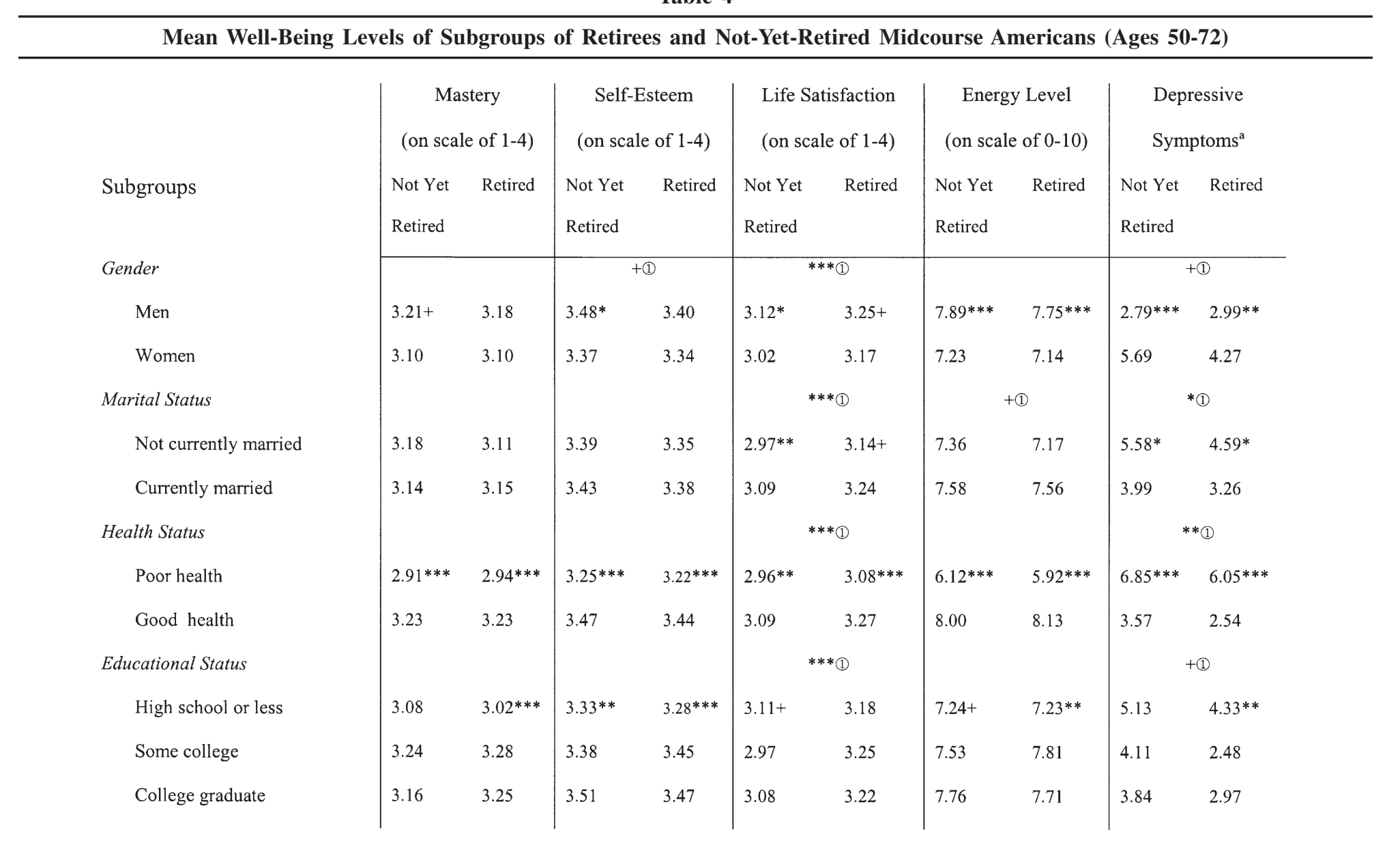


Table 4 (cont.)

\begin{tabular}{|c|c|c|c|c|c|c|c|c|c|c|}
\hline \multirow{2}{*}{$\begin{array}{l}\text { Income Status } \\
\quad \leq \$ 35,000\end{array}$} & & & \multicolumn{2}{|c|}{$* * *$ (1) } & \multicolumn{2}{|c|}{$* * *(1)$} & & & \multicolumn{2}{|c|}{$* * *(1)$} \\
\hline & $3.02 * *$ & $3.06^{* * *}$ & 3.25 & 3.31 & $2.98^{*}$ & 3.19 & $6.73^{* * *}$ & $7.32 * *$ & $5.76^{* *}$ & $4.18^{* *}$ \\
\hline$>\$ 35,000$ & 3.19 & 3.26 & 3.48 & 3.47 & 3.11 & 3.26 & 7.86 & 7.83 & 3.88 & 2.61 \\
\hline \multicolumn{11}{|l|}{ Place of Residence } \\
\hline Non-metropolitan & 3.10 & 3.11 & 3.44 & 3.38 & 3.06 & $3.28+$ & 7.24 & 7.32 & $4.85^{*}$ & $4.26+$ \\
\hline Metropolitan & 3.18 & 3.16 & 3.41 & 3.37 & 3.06 & 3.18 & 7.69 & 7.50 & 4.11 & 3.33 \\
\hline Age-Cohort & & & & & \multicolumn{2}{|c|}{$* *$ (1) } & & & & \\
\hline Ages $50-59$ & 3.16 & $3.23^{*}$ & 3.43 & 3.43 & 3.05 & 3.20 & 7.57 & 7.72 & 4.44 & 3.44 \\
\hline Ages $60-72$ & 3.09 & 3.11 & 3.33 & 3.36 & 3.11 & 3.21 & 7.30 & 7.39 & 4.02 & 3.64 \\
\hline & & & & & \multicolumn{2}{|c|}{$* * *$ (1) } & & & \multicolumn{2}{|c|}{$*_{(1)}$} \\
\hline Total & 3.15 & 3.14 & 3.42 & 3.37 & 3.06 & 3.21 & 7.53 & 7.46 & 4.37 & 3.60 \\
\hline (Standard Deviation) & $(.50)$ & $(.48)$ & (.44) & (.43) & $(.40)$ & $(.50)$ & $(1.74)$ & (1.94) & $(5.31)$ & (4.92) \\
\hline
\end{tabular}

Significance levels: $+\mathrm{p} \leq .1 \quad * \mathrm{p} \leq .05 \quad * * \mathrm{p} \leq .01 \quad * * * \mathrm{p} \leq .001 \quad$ (two-tailed tests)

a Center for Epidemiologic Studies Depression Scale (CES-D), a self-report measure of depressive symptoms

(1) Differences by retirement status. All other indications of significant difference are by subgroup within a retirement status.

Source: Cornell Retirement and Well-Being Study, Wave 1 (1994/95) N=762 
likely than newly retired men to do so (33.3\% of women vs. $17.9 \%$ of men), and those with low preretirement incomes are especially apt to begin formal volunteer work (those earning less than $\$ 35,000$ enter at a rate of $58.3 \%$, compared to $15.8 \%$ for those earning more than $\$ 35,000$ ).

\section{Does Participation Predict Well-Being?}

Table 4 presents average (mean) levels of our measures of well-being (at Wave 1) for various subgroups by retirement status. We find that levels of well-being, when statistically significant, are highest in every case for subgroups with the highest resource levels. This is true both for those midcourse Americans who have not yet retired and for retirees. (The one exception is life satisfaction; those not-yet-retired respondents with only a high school education rate their life satisfaction slightly higher than those who have some college education.) As might be expected, good health is positively related to each measure of psychological well-being for all midcoursers-both retirees and those who have not yet retired. Income is significantly and positively related to all measures of well-being (except life satisfaction for retirees, where the direction is as hypothesized, though the differences are not statistically significant). Being male, married or highly educated also tends to be associated with higher levels of well-being. Differences by place of residence and age are not as strongly associated with well-being. Among this midcourse sample of retirees and those not yet retired, rural residents tend to have a higher number of depressive symptoms. In general, the data confirm our expectations and are in line with prior research findings about the positive relationship between well-being and occupying an advantaged position in society.

Are Both Community Participation and Work Force Status Linked to Well-Being?

In Table 5 we present the coefficients from regressing various well-being measures on different aspects of social participation, estimated separately for the not-yet-retired older workers and retirees. We find that formal community participation (volunteering as part of organizational participation) is positively associated with well-being, but only for retirees. By contrast, neither informal "helping out" nor social club membership is significantly related to any measure of well-being. Retirees who are formal community volunteer participants (that is, engaged in volunteering as active members of community organizations) are the best off in terms of mastery, self-esteem, general life satisfaction and energy level. These differences in the links between community participation and well-being for retirees and not-yet-retired midcourse Americans are quite striking. The fact that we do not observe the same degree of relationship between community participation and well-being among the not-yet-retired workers provides support for our compensatory thesis: that formal com- 
munity participation might replace various salutary aspects associated with a career job. Individuals who formally participate in their communities by working as a volunteer for a local organization might have more opportunity to develop new social networks as well as to perform meaningful (though unpaid) work. This relationship between community participation and well-being is not as evident among those in the midcourse years who have not yet retired. For them, their career jobs may continue to be the primary source of purposive activity, identity, and social relations.

Analysis of the relationship between community participation and wellbeing at the time of the second wave (data not shown) reveals similar results to those from Wave 1 in that participation in formal volunteering seems to be most closely related to the well-being of midcourse retirees. The direction of the relationship between well-being and participation follows the same pattern for the newly retired as for those who retired earlier (by Wave 1), but the small numbers of newly retired make meaningful statistical analysis difficult.

We also see benefits of post-retirement employment, especially for American men in the midcourse years (data not shown). Retired men who are work-

Table 5

Unstandardized Regression Coefficients for the Relationship between Participation and Well-Being of Americans in the Midcourse Years, by Retirement Status

\begin{tabular}{|c|c|c|c|c|}
\hline & \multicolumn{4}{|c|}{ Dependent Variables } \\
\hline & Mastery & Self-Esteem & Satisfaction & $\begin{array}{l}\text { Energy } \\
\text { Level }\end{array}$ \\
\hline \multicolumn{5}{|l|}{ A. Not Yet Retired $(\mathrm{N} \sim 304)$} \\
\hline \multicolumn{5}{|l|}{ Social Participation } \\
\hline Informal "helping out" only & $.26 *$ & .14 & -.06 & .58 \\
\hline Social club member only & .06 & .08 & .03 & -.18 \\
\hline Formal community participation & .11 & $.12+$ & .00 & .11 \\
\hline \multicolumn{5}{|l|}{ Workforce Participation } \\
\hline Part time (versus full time) & .06 & -.08 & .04 & .17 \\
\hline \multicolumn{5}{|l|}{ B. Retirees $(\mathrm{N} \sim 458)$} \\
\hline \multicolumn{5}{|l|}{ Social Participation } \\
\hline Informal "helping out" only & -.03 & -.03 & .01 & .33 \\
\hline Social club member only & .08 & .08 & .04 & .32 \\
\hline Formal community participation & $.16 * *$ & $.18 * * *$ & $.14 *$ & $.64 * *$ \\
\hline \multicolumn{5}{|l|}{ Workforce Participation } \\
\hline Part time (versus not employed) & .09 & .04 & .03 & $.61 * *$ \\
\hline Full time (versus not employed) & $.12+$ & .10 & .04 & $.58+$ \\
\hline
\end{tabular}

Source: Cornell Retirement and Well-Being Study, Wave 1 (1994/95) 
ing for pay report higher levels of well-being (in terms of mastery, self-esteem, energy, general life satisfaction and a lower level of depressive symptoms) than do either non-employed retired men or retired women (regardless of the women's employment status).

In order to further examine the relationship between paid work and community participation we regressed well-being measures on community participation separately for two subgroups of retirees, divided according to their

paid work status. We found that for those retirees who are not involved in paid work, formal community participation is positively related to well-being in terms of every measure tested. These results provide further evidence for the proposition that community participation in the midcourse years may help to replace the loss of integrative, purposive activity associated with the world of paid work. Formal community participation, as opposed to simply "helping out" or participating in social clubs, may most closely approximate the typical paid work experience, providing routine, regular assignments, and on-going social relations, as well as the opportunity to help one's community.

However, community participation does not predict the well-being of midcourse retirees who are also working for pay. In fact, the only statistically significant link (number of depressive symptoms) indicates a negative association between well-being and community participation for these older postretirement workers. This relationship is an interesting one. Wuthnow (1991) points to the health dangers of community participation when it interferes with taking care of an individual's own needs first. Midcourse retirees in the U.S. who are actively engaged in both paid work and in formal volunteer work may find themselves overloaded in their obligations.

\section{The Contexts of Participation and Well-Being}

To determine whether community participation in the midcourse years is part of a process of cumulation of advantage (what Merton [1968] labels the Matthew effect, with those already well off also the most apt to benefit from social participation) or a compensatory process (with those less well off the most apt to benefit psychologically—see Bronfenbrenner and Morris [1998]), we regressed well-being measures on both community participation and employment participation separately for a number of subgroups. The results are presented in Table 6 .

Looking at the links between community participation and well-being measures for midcourse retirees in various categories (Table 6), there is evidence for both cumulation of advantage for already advantaged groups and compensation for the more disadvantaged subgroups. The fact that retired men (who tend to be more integrated in the sense that they are more apt to be married and/or in a post-retirement job) benefit more from both paid work and community participation than do retired women, and that those with at least some college benefit more (than those with only a high school education) 
Table 6

Relationship between Community Participation, Paid Work and Measures of WellBeing among Midcourse American Retirees (Ages 50 - 72), by Subgroup Characteristics

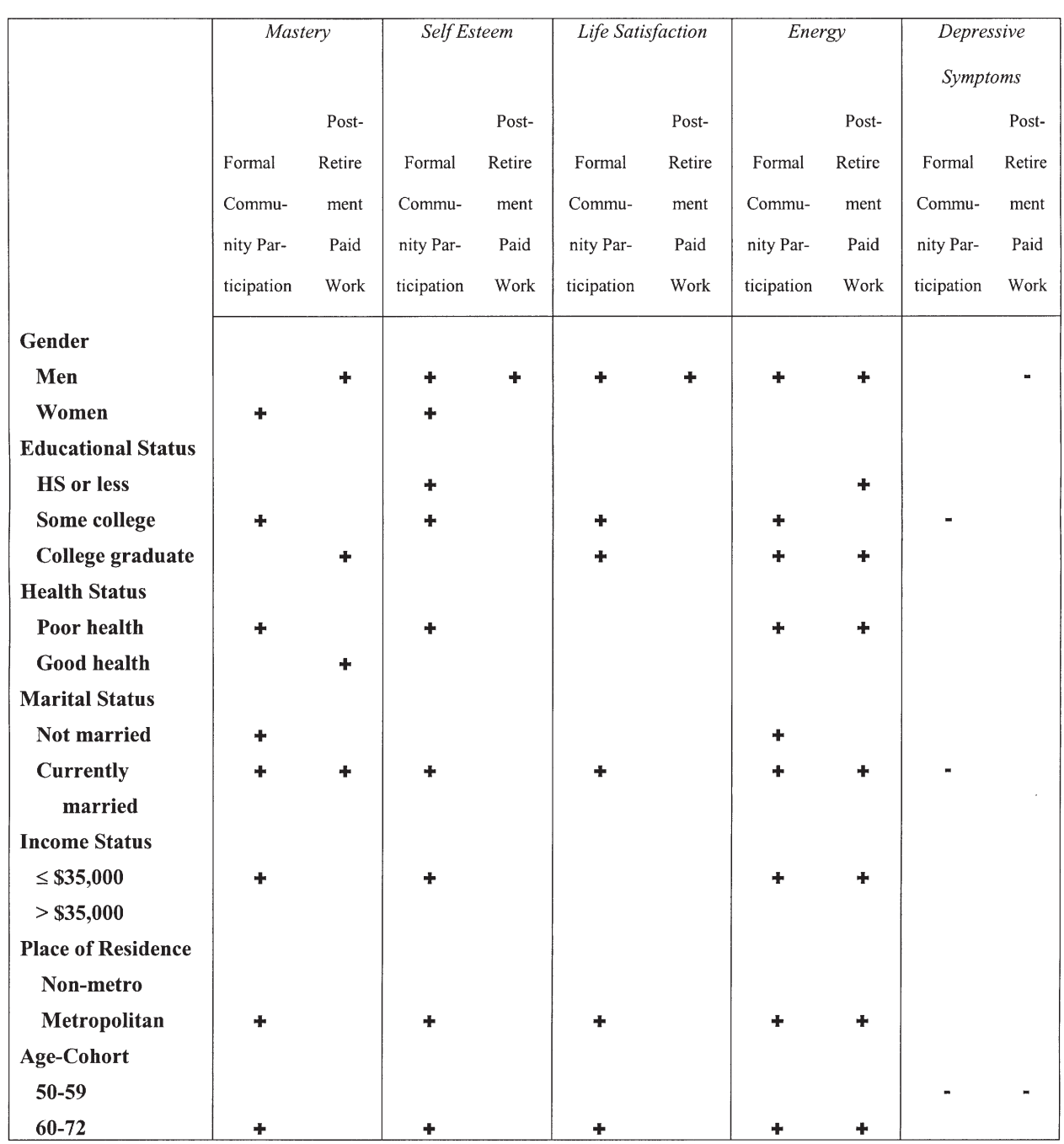

Note: Table shows significant regression coefficients when regressing well-being measures on various community participation and post-retirement employment measures within subgroups

Source: Cornell Retirement and Well-Being Study, Wave 1 (1994/95) $\quad$ N = 458 (twotailed tests) 
from community participation reinforces the "cumulation of advantage" hypothesis (Table 6). But there are disadvantaged subgroups who also appear to benefit from formal community participation: those in poor health, those with lower incomes, and those in their $60 \mathrm{~s}$ and early 70 s. Note that neither informal volunteering nor being a member of a social club is significantly related to well-being for any of the subgroups.

\section{Discussion and Conclusions}

Life changes such as retirement can be both beneficial and detrimental to individual development (Cooper, 1990). We suggest that whether the midcourse status passage of retirement has positive or negative implications for psychological well-being depends in part on the social connectedness of retirees. Since jobs provide routine, ritual, relationships, and role identity, retirement from one's career job restructures not only life patterns but also self-conceptions and social relations, especially in the United States, where such a premium is placed on paid work. But Americans, like Canadians, are also active volunteers in their communities, joining organizations to make the world a better place. By contrast, Europeans are less apt to do unpaid volunteer work, given that the Welfare State provides much of the supports that are provided only on a voluntary basis in the United States. In this study we addressed two questions: First, do Americans in the midcourse years (in their 50s, 60s, 70s) replace the connectedness associated with their career jobs with formal community volunteer participation or other unpaid participation (either informal "helping out" or social clubs) following retirement? And second, is formal community volunteer participation more consequential for well-being when midcoursers are retired?

The retirement transition can be viewed as a dialectical process, producing changes in both individuals' social environments as well as in their subjective interpretations of themselves and their lives, with changes in one impinging on changes in the other (Kim \& Moen, 2001a, 2001b, 2002; Moen et al., 2001). We find little difference in the rates of unpaid participation between the not-yet-retired and retired midcourse Americans in our sample. Nor do we find major differences in the rates of change in such participation over a twoyear period between those who make the transition to retirement, those who remain in their career jobs, and those who were already retired (although trends suggest an increase in formal community participation among some groups of newly retired). What is most striking is our evidence of differences in links between community participation and well-being by retirement status, suggesting that formal community participation may become more consequential for the well-being of midcourse Americans following their retirement. The fact that formal volunteer service for one or more community organizations predicts the well-being of midcourse retirees, not those who haven't yet retired, and, moreover, only for midcourse retirees who do not take on subse- 
quent employment, suggests that the salience of such participation depends on whether individuals are also engaged in paid work.

Employment without doubt continues to be the principal source of social connectedness not only for Americans, but for most adults everywhere. The meaning of employment in advanced societies across the globe is the opportunity it provides to participate, to make a contribution, to do something meaningful as well as to earn a living. Retirement from paid work can cut individuals off from that participation as well as from the identity and sense of community it provides. We have not shown that, net of all other factors, volunteering is the panacea to well-being. In fact, our goal was not to model well-being as a linear effect of many disparate variables. Our focus, rather, is on the person, not the variable, and whether that person is or is not retired, employed, participating in their community in some way. What our evidence suggests is the potential value of unpaid community participation, in the form of volunteer work in organizational settings, especially for those midcourse Americans no longer engaged in paid work.

Mature adulthood has been characterized as vital involvement in life's generative activities (Erikson, Erikson, \& Kivnick, 1986). In this study we have documented that formal volunteer participation with others in meaningful community activities is related to the psychological well-being of midcourse Americans in retirement. But this is of course complicated by selection effects. Who choses to volunteer, or to work after retirement, and why? Our evidence shows that those retirees who are most advantaged in society are also the most apt to participate in formal volunteer service and to benefit psychologically from that participation. But some more disadvantaged segments of the retiree population also appear to benefit from community participation: those in poor health and those with low incomes who do formal volunteer work for an organization are likely to be better off psychologically.

Americans make choices throughout adulthood, not only about their jobs but also about whether and when to participate in their communities (Pillemer et al., 2000). These choices then play out in the likelihood of subsequent community participation in retirement. But recall that the very nature of retirement is changing as we witness a new life stage, midcourse between early career development and old age (Moen, 2002). Midcourse is a time of flux. In the United States, both midcourse workers and midcourse retirees may be working for pay, both midcourse retirees and midcourse workers may be active in their communities, and midcoursers may "retire" several times over. These changes suggest that scholars should examine not only individuals but also features of the institutional environment shaping choices about workforce participation and community participation in the midcourse years (see also Kohli, 1986; Riley, Kahn, \& Foner, 1994).

Both the emerging midcourse life stage and the retirement transition embedded within it can offer opportunities for the development of new identities and can foster on-going engagement in various forms of paid and unpaid 
activities. In the United States, midcourse retirees who are working for pay or actively participating in their communities without pay seem to be the best off in terms of life quality. Moreover, they themselves constitute an untapped pool of potential volunteers who can invest in their communities (Freedman, 1993, 1999). But existing structural arrangements, policies, norms, and practices fail to provide the opportunities, roles, and challenges that can fully exploit the possibilities of life-and well-being-in the midcourse years. As we witness an aging workforce and increasing longevity - in Europe and Canada, as well as the United States, existing life course regimes institutionalizing retirement as a oneway, one-time permanent exit from productive engagement are out of date. What is required are a range of midcourse pathways, including gradual (phased)retirement over a period of years, opportunities for post-retirement paid work, social recognition of the value of formal but unpaid community participation, and the institutionalization of such civic service into the fabric of contemporary society.

\section{Biographical Notes}

Corresponding author: Phyllis Moen, Cornell University, G58 MVR, Ithaca, NY 14853; e-mail: pem3@cornell.edu.

Phyllis Moen is Ferris Family Professor of Life Course Studies, Professor of Sociology and of Human Development, founding director of the Bronfenbrenner Life Course Center, and director of the Cornell Employment and Family Careers Institute at Cornell University. She does research on gender, age, and the life course.

Vivian Fields, former Project Manager of the Cornell Retirement and Well-Being Study, has been researching issues regarding aging and retirement for over 20 years. Her previous research includes such topics as women in retirement, Social Security's effect on retirement age, and the feasibility of partial retirement.

\section{Notes}

The authors would like to thank Madhurima Agarwal, Roger Brunson, Sonia Cheng, Carrie Chu, Jenn Dickman, Bill Erickson, Mary Ann Erickson, Shin-Kap Han, Chuck Henderson, Heather Hofmeister, Brenda Neal, Heather E. Quick, Julie Robison, Leslie Schultz, Deborah Smith, Sireesha Soma, Laurie Todd, and David Warner for their work on the Cornell Retirement and Well-Being Study, as well as Marin Clarkberg, Richard P. Shore, and Vandana Plassmann for their comments, and Sarah Jaenike Demo for her skilled manuscript preparation.

This research was supported by grants \#P50 AG11711-01 and \#P50AG11711-06 from the National Institute on Aging (Karl Pillemer and Phyllis Moen, Co-Principal Investigators), and grant \#96-69 and 99-6-23 from the Alfred P. Sloan Foundation (Phyllis Moen, Principal Investigator).

\section{References}

Atchley, R. C. (1989). A continuity theory of normal aging. Journal of Personality and Social Psychology, 29, 183-190.

Baltes, P. B., \& Baltes, M. M. (Eds.) (1990). Successful aging: Perspectives from the behavioral sciences. Cambridge, England: Cambridge University Press. 
Barfield, R. E. (1970). The automobile worker and retirement. Ann Arbor: University of Michigan, Institute of Social Research.

Boskin, M. J. (1977). Social security and retirement decisions. Economic Inquiry, 15, 1-25.

Bronfenbrenner, U., \& Morris, P. A. (1998). The ecology of developmental processes. In R. M. Lerner \& W. Damon (Eds.), Theory, Volume 1 of Handbook of child psychology (5th ed.), (pp. 993-1028). New York: Wiley.

Caro, F. G., \& Bass, S. A. (1995). Increasing volunteering among older people. In S. A. Bass (Ed.), Older and active: How Americans over 55 are contributing to society (pp. 7196). New Haven: Yale University Press.

Caro, F. G. etc. (1997). Receptivity to volunteering in the immediate postretirement period. The Journal of Applied Gerontology, 16, 427-444.

Chambré, S. M. (1984). Is volunteering a substitute for role loss in old age? An empirical test of activity theory. The Gerontologist, 24, 294-295.

Chambré, S. M. (1987). Good deeds in old age: Volunteering by the new leisure class. Lexington, MA: Lexington.

Chirikos, T. N., \& Nestel, G. (1989). Occupation, impaired health, and the functional capacity of men to continue working. Research on Aging, 11, 174-205.

Clausen, J. A., \& Gilens, M. I. (1990). Personality and labor force participation across the life course: A longitudinal study of women's careers. Sociological Forum, 5, 595-618.

Cooper, C. L. (1990). Coping strategies to minimize the stress of transitions. In S. Fisher \& C. L. Cooper (Eds.), On the move: The psychology of change and transition (pp. 315328). Chichester, England: John Wiley and Sons.

Elder, G. H., Jr. (1995). The life course paradigm: Social change and individual development. In P. Moen, G. H. Elder, Jr., \& K. Lüscher (Eds.), Examining Lives in Context: Perspectives on the Ecology of Human Development (pp. 101-139). Washington, DC: American Psychological Association.

Erikson, E. H., Erikson, J. M., \& Kivnick, H. Q. (1986). Vital involvement in old age. New York: Norton.

Fengler, A. P. (1984). Life satisfaction of subpopulations of elderly: The comparative effects of volunteerism, employment and meal site participation. Research On Aging, 6, 189-212.

Fengler, A. P., Little, V. C., \& Danigelis, N. L. (1983). Correlates of dimensions of happiness in urban and nonurban settings. International Journal of Aging and Human Development, 16, 53-65.

Fischer, L. R., \& Schaffer, K. B. (1993). Older volunteers: A guide to research and practice. Newbury Park, CA: Sage.

Freedman, M. (1993). The kindness of strangers. San Francisco: Jossey Boss.

Freedman, M. (1999). Prime time: How baby boomers will revolutionize retirement and transform America. New York: Public Affairs.

Friedmann, E., \& Havighurst, R. I. (1954). The meaning of work and retirement. Chicago: University of Chicago Press.

George, L. K., \& Maddox, G. L. (1977). Subjective adaptation to loss of the work role: A longitudinal study. Journal of Gerontology, 32, 456-462.

Gilespie, D. F., \& King, A. E. (1985). Demographic understanding of volunteerism. Journal of Sociology and Social Welfare, 12, 798-816.

Han, S.-K., \& Moen, P. (1999). Clocking out: Temporal patterning of retirement. American Journal of Sociology, 105, 191-236. 
Hayward, M. D., Hardy, M. A., \& Grady, W. R. (1990). Work and retirement among a cohort of older men in the United States, 1966-83. Demography, 27, 337-356.

Henretta, J. C., \& O'Rand, A. M. (1980). Labor force participation of older married women. Social Security Bulletin, 43, 29-39.

Herzog, A. R., Kahn, R. L., Morgan, J. N., Jackson, J. S., \& Antonucci, T. C. (1989). Age differences in productive activities. Journal of Gerontology: Social Sciences, 44, 129-38.

Herzog, A. R., \& Morgan, J. N. (1993). Formal volunteer work among older Americans. In S. A. Bass, F. G. Caro \& Y.-P. Chen (Eds.), Achieving a productive aging society (pp. 119-142). Westport, CT: Auburn House.

Jahoda, M. (1982). Employment and unemployment: A social psychological analysis. New York: Cambridge University Press.

Juster, F. T. (1992). Health and retirement survey. Ann Arbor: Survey Research Center, Institute for Social Research, University of Michigan.

Kahn, R. (1981). Work and health. New York: John Riley.

Kessler, R. C., Turner, J. B., \& House, J. S. (1989). Unemployment, reemployment, and emotional functioning in a community sample. American Sociological Review, 54, 648-57.

Kim, J., \& Moen, P. (2001a). Moving into retirement: Preparation and transitions in late midlife. In M. Lachman (Ed.), Handbook of Midlife Development (pp. 487-527). New York: John Wiley \& Sons.

Kim, J., \& Moen, P. (2001b). Is retirement good or bad for subjective well-being? Current Directions in Psychological Science, 10, 83-86.

Kim, J., \& Moen, P. (2002). Retirement transitions, gender, and psychological well-being: A life-course, ecological model. Journal of Gerontology: Psychological Sciences 57B, P221-P222.

Kohli, M. (1986). Social organization and subjective construction of the life course. In A. B. Sorensen, F. E. Weinner, \& L. R. Sherrod (Eds.), Human development and the life course: Multidisciplinary persectives (pp. 271-292). Hillsdale, NJ: Lawrence Erlbaum.

Kuehne, V. S., \& Sears, H. A. (1993). Beyond the call of duty: Older volunteers committed to children and families. Journal of Applied Gerontology, 12, 425-438.

Longino, C. F., \& Kart, C. S. (1982). Explicating activity theory: A formal replication. Journal of Gerontology, 37, 713-722.

Marriott Senior Living Services. (1991). Marriott seniors volunteerism study (Marriott Senior Living Services and U.S. Administration on Aging), April 1991.

McPherson, J. M. (1981). A dynamic model of voluntary affiliation. Social Forces, 59, 705-728.

Merton, R. K. (1968). Social theory and social structure. New York: The Free Press.

Moen, P. (1996). A life course perspective on retirement, gender, and well-being. Journal of Occupational Health Psychology, 1, 131-144.

Moen, P. (1997). Women's roles and resilience: Trajectories of advantage or turning points? In I. H. Gotlib \& B. Wheaton (Eds.), Stress and adversity over the life course: Trajectories and turning points (133-156). New York: Cambridge University Press.

Moen, P. ( 2001). The gendered life course. In L. George \& R. H. Binstock (Eds.), Handbook of aging and the social sciences, 5th edition (pp. 179-196). San Diego, CA: Academic Press, Inc.

Moen, P. (2002). Midcourse: Navigating retirement and a new life stage. Forthcoming in J. T. Mortimer \& M. J. Shanahan (Eds.), Handbook of the Life Course. New York: Kluwer Academic/Plenum Publishers. 
Moen, P., Dempster-McClain, D., \& Williams, R. M., Jr. (1992). Successful aging: A life course perspective on women's roles and health. American Journal of Sociology, 97, 1612-1638.

Moen, P., Fields, V., Quick, H., \& Hofmeister, H. (2000). A life course approach to retirement and social integration. In K. Pillemer, P. Moen, E. Wethington, \& N. Glasgow (Eds.), Social integration in the second half of life (pp. 75-107). Baltimore: The Johns Hopkins Press.

Moen, P., \& Han, S.-K. (2001). Gendered careers: A life course perspective. In R. Hertz \& N. Marshall (Eds.), Working Families: The Transformation of the American Home (pp. 4257). Berkeley, CA: University of California Press.

Moen, P., Kim, J. E., \& Hofmeister, H. (2001). Couples' work/retirement transitions, gender, and marital quality. Social Psychology Quarterly, 64, 55-71.

Musick, M. A., Herzog, A. R., and House, J. S. (1999). Volunteering and mortality among older adults: Findings from a national sample. Journal of Gerontology: Social Sciences, 54B, S173-S180.

Neugarten, B., Havighurst, R. J., \& Tobin, S. S. (1961). The measurement of life satisfaction. Journal of Gerontology, 16, 134-143.

Newmann, J. P. (1989). Aging and depression. Psychology and Aging, 4, 150-165.

Okun, M. A., Stock, W. A., Haring, M. J., \& Witter, R. A. (1984). The social activity / subjective well-being relation: A quantitative synthesis. Research on Aging, 6, 45-65.

O'Rand. A. M. (1995). The cumulative stratification of the life course. In R. H. Binstock and L. K. George (Eds.), The handbook of aging and the social sciences, 4th edition (pp. 188-207). San Diego, CA: Academic Press.

Parnes, H. S., \& Nestel, G. (1974). Early retirement. In H. S. Parnes, et al. (Eds.), The preretirement years: Five years in the work lives of middle-aged men (pp. 153-196). Columbus: Center for Human Resources Research, Ohio State University.

Pavalko, E. K., Elder, G. H. Jr., \& Clipp, E. C. (1993). Work lives and longevity: Insights from a life course perspective. Journal of Health and Social Behavior, 34, 363-380.

Pearlin, L. I., Menaghan, E. G., Lieberman, M. A., \& Mullan, J. T. (1981). The stress process. Journal of Health and Social Behavior, 22, 337-356.

Pearlin, L. I., \& Schooler, C. (1978). The structure of coping. Journal of Health and Social Behavior, 19, 2-21.

Pienta, A. M., Hayward, M. D., \& Jenkins, K. R. (2000). Health consequences of marriage for the retirement years. Journal of Family Issues, 21, 559-586.

Pillemer, K., Moen, P., Wethington, E., \& Glasgow, N. (Eds.). (2000). Social integration in the second half of life. Baltimore: The Johns Hopkins Press.

Putnam, R. D. (1993). The prosperous community: Social capital and public life. The American Prospect, 13, 35-42.

Quick, H., \& Moen, P. (1998). Gender, employment, and retirement quality: A life course approach to the differential experiences of men and women. Journal of Occupational Health Psychology, 3, 44-64.

Quinn, R. P., \& Staines, G. L. (1979). The 1977 quality of employment survey. Ann Arbor: Survey Research Center, Institute for Social Research, University of Michigan.

Radloff, L. S. (1977). The CES-D scale: A self report depression scale for research in the general population. Applied Psychological Measurement, 1, 385-401.

Riley, M. W., Kahn, R. L., \& Foner, A. (Eds.) (1994). Age and structural lag: The mismatch between people's lives and opportunities in work, family, and leisure. New York: John Wiley \& Sons. 
Rosenberg, M. (1965). Society and the adolescent self-image. Princeton: Princeton University Press.

Rosenfield, R. A. (1980). Race and sex differences in career dynamics. American Sociological Review, 42, 210-217.

Rowe, J. W., \& Kahn, R. L. (1987). Human aging: Usual and successful. Science, 237, 143-149.

Ruhm, C. J. (1990). Career, jobs, bridge employment, and retirement. In P.B. Doeringer (Ed.), Bridges to retirement. Ithaca, NY: ILR Press, Cornell University.

Ryff, C. D., \& Keyes, C. L. M. 1995. The structure of psychological well-being revisited. Journal of Personality and Social Psychology, 69, 719-727.

Siegel, J. S. (1993). A generation of change: A profile of America's older population. New York: Russell Sage.

Sorenson, A. (1983). Women's employment patterns after marriage. Journal of Marriage and the Family, 45, 311-321.

Spitze, G., Logan, J. R., Joseph, G., \& Lee, E. (1994). Middle generation roles and the wellbeing of men and women. Journal of Gerontology: Social Sciences, 49, S107-S116.

Streib, G. F., \& Schneider, C. J. (1971). Retirement in American society. Ithaca, NY: Cornell University Press.

Terkel, S. (1985). Working. New York: Ballantine.

Tomeh, A. K. (1973). Formal voluntary organizations: Participation, correlates, and interrelationships. Sociological Inquiry, 43, 89-122.

Waite, L. J., \& Gallagher, M. (2000). The case for marriage: Why married people are happier, healthier, and better off financially. New York: Doubleday.

Waldron, I., \& Jacobs, J. A. (1989). Effects of multiple roles on women's health: Evidence from a national longitudinal study. Women and Health, 15, 3-19.

Weiss, R. (1990). Losses associated with mobility. In S. Fisher \& C. L. Cooper (Eds.), On the move: The psychology of change and transition (pp. 3-12). Chichester, England: John Wiley and Sons.

Weiss, R. (1997). Adaptation to retirement. In I. H. Gotlib \& B. Wheaton (Eds.), Stress, and adversity over the life course (pp. 232-248). New York: Cambridge University Press.

Wilson, J. (2000). Volunteering. Annual Review of Sociology, 26, 215-240.

Wilson, J., \& Musick, M. (1997). Who cares? Toward an integrated theory of volunteer work. American Sociological Review, 62, 694-713.

Wilson, W. J. (1995). Jobless ghettos and the social outcome of youngsters. In P. Moen, G. H. Elder, Jr. \& K. Lüscher (Eds.), Examining lives in context (pp. 527-543). Washington, DC: American Psychological Association.

Wuthnow, R. (1991). Acts of compassion: Caring for others and helping ourselves. Princeton: Princeton University.

Young, F. W., \& Glasgow, N. (1998). Voluntary social participation and health. Research on Aging, 20, 339-362.

* Invited paper: Revised manuscript accepted for publication in April, 2002. Action Editor: P.S. Fry. 
Copyright $\odot 2002$ EBSCO Publishing 
Copyright $\odot 2002$ EBSCO Publishing 